展望・解説

\title{
回転鏡式高速度カメラの試作と応用*
}

小野寺 英輝**

\section{Design of Rotating Mirror Type High Speed Camera and Its Apprication for Shock Wave Research}

\author{
Hideki ONODERA
}

\section{1.はじめに}

高速現象の計測を目的とした可視化については， 19世紀末のE. Machによる飛翔弾丸の撮影を喵矢 として，爾来さまざまの方法が行われてきている。 特に工業火薬の分野では，古くから高速度撮影に よる現象の解析が行われてきており，これは大規 模爆発実験においては特に有効な解析手段である。 この研究の流れは, まず回転プリズム式の高速度 カメラによる爆速の計測にはじまるが，その時間 解像度（一般的には $2 \times 10^{5}$ fps; flames per second, 程度が最高)および空間解像度 (10 lines $\mathrm{mm}$ 程度)の制約から，現象の巨視的把握にとどま っていだ。

その後，ドラムカメラを用いた高速度撮影が盛 んになった がが，一般に，光源に用いるキセノン放 電管の発光パルス幅はたかだか $1 \mu \mathrm{s}$ 程度で, 普通 の高速現象の観测には適当であるが，たと之ば， 空気中の強い衝撃波，あるいは透明な固体や水中 の衝撃波のような超高速現象の可視化計測には十 分でない。そこでその後，イメージコンバータチ ユーブ (転像管) を用いる方法が発達することに なった。この方法は，ストリーク撮影もでき，取 扱が簡単で有効であるが，記録画像数が制限され， また画像の解像度も10 lines / mm程度という制 約がある。そこで，このような欠点を補うべく著

*原稿受付 1995年 1 月 6 日

**正会員 岩手大学地域共同研究センター
者らの開発した回転鏡式 (ドラム) カメラ ${ }^{3), 4}$ につ いて以下に紹介したい。

\section{2. 試作カメラ}

試作したカメラの主要諸元を表 1 に，その概形 を図 1 に示す。このドラムカメラは外径 $900 \mathrm{~mm}$, 厚さ100mmで，ドラム内側のフィルムが拥入され

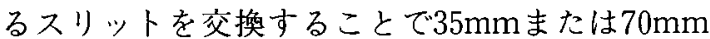
の長尺ロールフィルムが使用できるようになって いる。

衰 1 試作カメラの主要諸元

\begin{tabular}{l|l}
\hline Outside diameter & $900 \mathrm{~mm}$ \\
Outside Thickness & $100 \mathrm{~mm}$ \\
Film Length & $2500 \mathrm{~mm}$ \\
Supply Pressure & 0 to $0.36 \mathrm{MPa}$ \\
Mirror Rotation Speed & 0 to $220,000 \mathrm{rpm}$ \\
Spatial Resolution & 25 lines $/ \mathrm{mm}$ \\
& (at $\left.4 \times 10^{6} \mathrm{frames} / \mathrm{s}\right)$ \\
Frames & 1 to $40 \mathrm{frames}$ \\
Streak Rate & max $100 \mathrm{~ns} / \mathrm{mm}$ \\
\hline
\end{tabular}

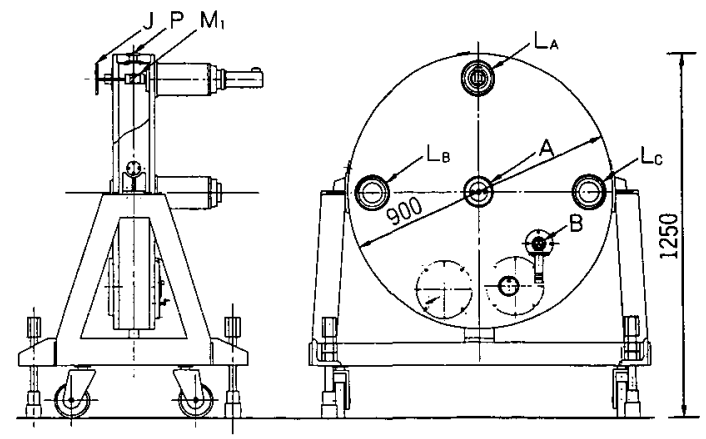

図 1 試作カメラの外観図 
ドラム形式を持つ高速度カメラには回転ドラム 式と回転鏡式の 2 種類があるが, 試作カメラでは 高速回転に有利である後者の形式を採った。

さて，鏡が高速回転すると，その周辺には衝撃 波が発生することが知られている。この衝撃波は 造波抵抗になるばかりでなく, 内部構造に不要の 擾乱を与え，画像に歪みを与える。そこで，試作 カメラには, これを軽減するために, 内部の排気 が可能な機構を組み込んだ。また, 内部が負圧と なることでカメラのふたは非常に大きな外力にさ らされるので, これを考慮して, その厚みを $20 \mathrm{~mm}$ とし，中間支持柱をもつ構造とした。

また，試作したドラムカメラは，同一構造の三 つの受光部 $\mathrm{L}_{\mathrm{A}}, \mathrm{L}_{\mathrm{B}}, \mathrm{L}_{\mathrm{C}}$ を有し, 光学系を工夫する と, 装媜されたフィルムに, 同一現象を同時に異 なる 3 方向から，それぞれ角度 90 度間隔で記録で きる。実際には回転鏡の制約からこの円弧のうち 有効に記録に利用できる部分はそれぞれ約 45 度の 範囲である。なお， J は画像を $\mathrm{R} M$ 上の適切な位 置に送るための $\mathrm{M}_{1}$ の調節つまみである。

図 2 にカメラ本体から取り出した受光部を,

図 3 にカメラの内部を示す。受光部に入射した光 は, 内部の写真の引き伸ばし機用のレンズを利用 したリレーレンズ系を通り, $\mathrm{M}_{1}$ で反射し, さらに

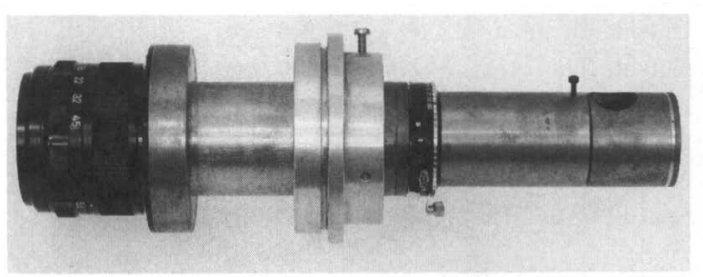

图 2 受光部ユニット（リレーレンズと取付部）

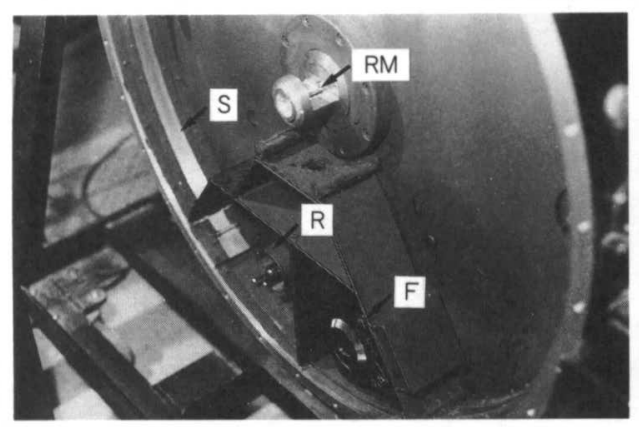

(RM:回転鏡, S: フィルムスリット, F:フィルム 繰出し部, R:フィルム卷取部)

図 3 ドラムカメラ内部
カメラ本体中央部の 8 角形の回転鏡 RM（鏡面有 効長 $20 \mathrm{~mm}$, 一面の有効幅 $4 \mathrm{~mm}$, 重量 $16.4 \mathrm{~g}$ ) で反 射して, それぞれのチャンネルに対応するフィル ム上に結像する。この回転鏡は, 超高速回転に伴 い空気との摩擦抵抗により発熱するので, 耐熱性 に優れたチタン合金製とした。

さて，回転鏡式のカメラにおいて，その撮影間 隔を縮め, 時間解像度を向上させるためには, 光 源の発光間隔を短くすることが必要なのは当然で ある。しかしそれ以上に, 隣接するコマの撮影像 の重畳を防ぐために, 回転鏡の回転数を従来に比 して格段に増大させる必要がある。そこで試作機 では, 電動機に比して容易に超高速が得られるド リル用のエアタービン（東芝タンガロイ製TPFス ピンドルTPF-15A)を使用することとした。ター ビンの駆動には高圧空気を用い, その供給圧力を 変えることで回転数を制御した。圧力をゲージ圧 $0.1 \sim 0.36 \mathrm{MPa}$ 範囲で変えることにより, カメ ラ内部が大気圧の状態で, 回転鏡の回転数は最高 220,000rpmまで連続的に制御できた。図4(a)に

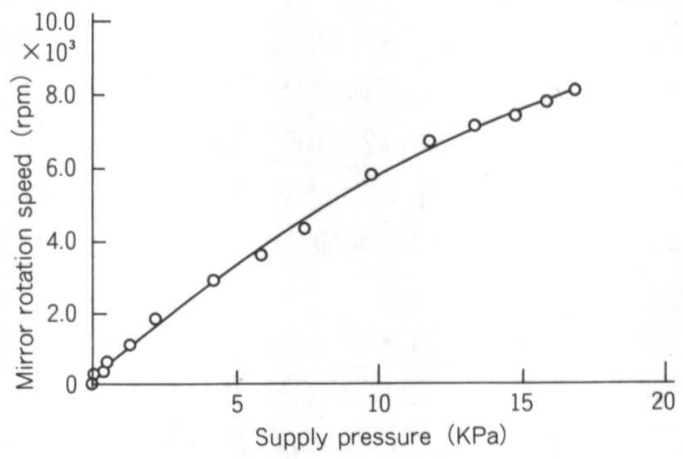

（a）低速回転領域 $\left(0 \sim 8 \times 10^{3} \mathrm{rpm}\right)$

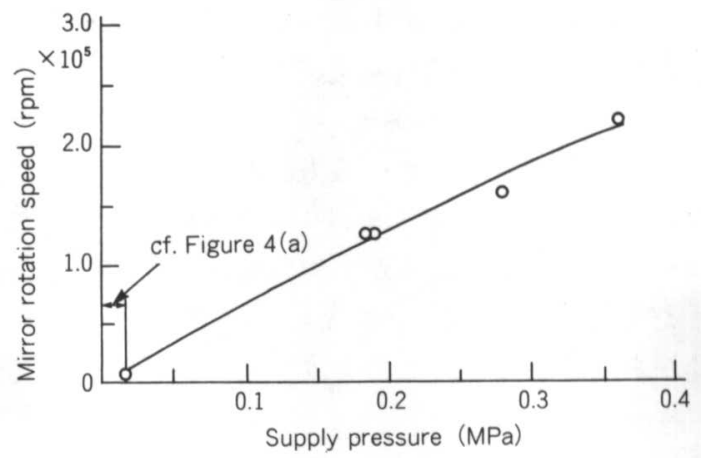

(b) 高速回転領域 $\left(8 \times 10^{3} \sim 2.2 \times 10^{5} \mathrm{rpm}\right)$

図 4 タービン給気圧と回転鏡回転数の関係 
低速域, 図 4 (b)に高速域のタービンへの供給空 気圧と回転鏡回転数の関係を示す。エアターピン は低速域から高速域まで, 滑らかで連続的な回転 数変化を示し回転数制御が容易であることがわか る。なお，このエアタービンは空気軸受けを使用 しており，運転中は $0.3 \mathrm{MPa}$ 程度の圧力を軸受に 常時印加している必要がある。そのため容量 0.5 $\mathrm{m}^{3}$ 程度のエアリザーバをコンプレッサ・タービン 間に設置し運転時の供給圧力の低下を防いだ。さ らに，圧縮空気中の水分を除去するため複数段の エアフィルタを挿入した。単段のフィルタでは水 分が軸受けに達して目づまりの原因となり，一度 軸受けの焼き付きを引き起こした。

回転鏡回転数の計測は，低速域では，CWレー ザ光を受光部から入射させ，その回転鏡からの反 射光をドラム周上のファインダ部に設置したフォ トセルで受け, 出力をユニバーサルカウンタで計 測することにより行った。しかし，高速域では， 光源の発光周波数がフォトセルの立ち上がり時間 を上回り，計測が不可能となったため，実際にカ メラを作動させ，光源の発光をフィルムに記録し て, 各コマの間隔から回転数を計測する方法を採 つた。

撮影に用いた $35 \mathrm{~mm}$ 長尺フィルムは，明室でパ トローネへフィルムを装填する際に使用する器具 を改造したフィルム繰り出し装置 (図3F) から力 メラ外部のつまみ操作により繰り出され, 円筒内 面の周上の溝 Sに沿って全周にわたって容易にセ ットされる。この溝には小孔が一様にあけられ， フィルムを円筒内面の周上に真空吸引して固定で きる。フィルムの卷取りは, 撮影後 F の位置でフ イルム切断後フィルム巻取り部 Rのつまみにより カメラ外部から容易に行える。
撮影像の焦点合わせは，まず，ドラム外周に 3 か所設けたファインダー用の孔に, 焦点面がフィ ルム面と同一の高さになるように製作したファイ ンダーを挿入して行う。焦点合わせ終了後はその 部分に真鍮製のアタッチメントを挿入し, 遮光を はかるようにした。

これらの装置は一部外注で加工した部分もある ものの, 主要部分の製作は東北大学流体科学研究 所附属工場で行った。全製作費用は約 $3,000,000$ 円 であった。

\section{4. 光源と撮影例}

\section{1 キセノンフラッシュランプ}

まず最初に光源として, 高圧火花発生装置（菅 原研究所MM-305AA, 出力最大 $4 \mathrm{~J} / \mathrm{Pulse}$ ) とキ セノンフラッシュランプを組み合わせたものを用 い, パルス幅約 $1 \mu \mathrm{s}$ (約 $1 \mathrm{~J} /$ Pulse) で撮影を行っ た。

図 5 は二酸化炭素雾囲気中で $10 \mathrm{mg}$ のアジ化銀 ペレット（直径約 $1.5 \mathrm{~mm} \times$ 長さ約 $1.5 \mathrm{~mm}$, 密度約 $3.77 \mathrm{~g} / \mathrm{cm}^{3}$, 中国化薬製) を直径 $0.6 \mathrm{~mm}$ のグラス ファイバー先端に接着し，それをYAGレーザ

(Laser Photonics製, LPI/model MYL-100, 出力 $25 \mathrm{~mJ} /$ pulse, パルス幅7nsec, 波長1.064 $\mu \mathrm{m}$ ) を用いて起爆した場合の様子を撮影したものであ る。この光源では, 内蔵するコンデンサの容量の 制約から発光数が制限され，ここに示したパルス 間隔 $55 \mu \mathrm{s}$ の場合, 発光数は 25 となり, 全記録時間 は $1320 \mu \mathrm{s}$ なる。これより一段階発光間隔をせば めることも可能であるが, この場合, 一つのパル ス当たりのエネルギが減少し, 写真撮影が困難と なった。なお, 爆発実験を二酸化炭素雲囲気中に おいて行ったのは, 光源の発光間隔の広さを補う

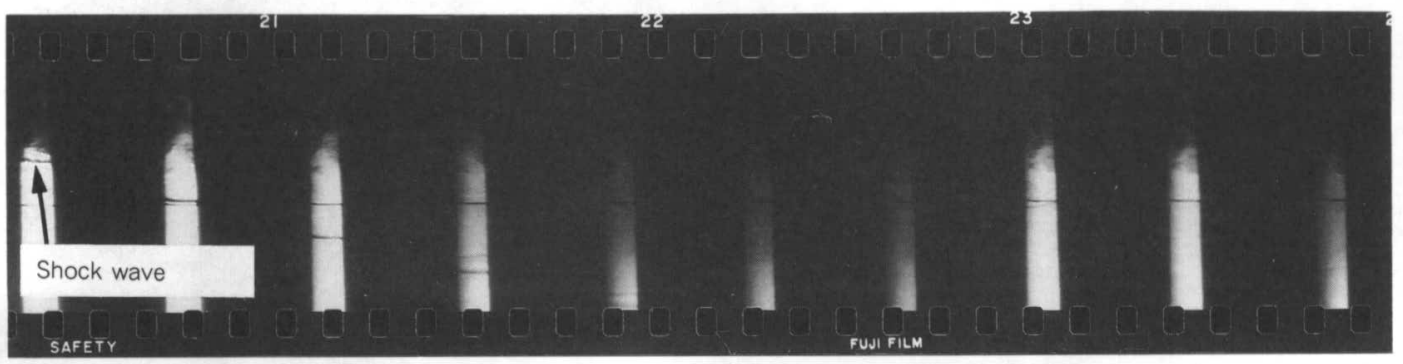

図 5 気中微小爆発の可視化 $\left(\mathrm{AgN}_{3}-10 \mathrm{mg}\right.$, キセノンフラッシュ光源, シャドウグラフ法 $)$ 
ために音速を減少させ，衝撃波伝播速度を低下さ せることにより，球状衝撃波を捕捉するコマ数を 増加させるためである（性能試験のため，このよ うな操作を行った)。

さて, 撮影像は, 発光パルス幅が約 $1 \mu \mathrm{s}$ と長いた め，わずかに衝撃波面のぶれが見られるものの， 鮮明な衝撃波を捕捉できている。しかしながら, 発光間隔が長いため, 前述のような音速を低下さ せる操作を行ってもなお, 数コマ程度しか波面を 捕捉できない。この光源は, 発光間隔が長く時間 解像度が劣るが, 比較的安価で光量も十分であり 低速現象には適する。

\section{2 キャビティダンパ付きアルゴンイオンレーザ}

\subsection{1. キャビティダンパ}

アルゴンイオンレーザは通常連続光のみを出力 する。しかし, 光路上にキャビティダンパという 装置を設置することで, 連続的にパルス発光を行 わせることができる。

キャビティダンパの作動原理の概略を図 6 に示 す。イオンレーザから発射されたレーザ光は, プ リズムを経てM2で反射し, ブラグセルと呼ばれる 溶融ガラス製の変調器で振動波と干渉し, キャビ ティダンパ終端鏡M1に達する。この光線は同一光 路をM3に向かってもどり, 再びM1に向かう。一 方, ブラグセルで, 振動波と干渉して生じたパル ス状の回折光は, 入射光と別光路を経てM1，M2 で反射しプリズムを経て発射される。非発射時の エネルギはキャビティダンパの光路で蓄えられる ことになるので，パルス幅に対応する時間におけ る光線のエネルギはキャビティダンパを使用した 方が大きくなる。また, 撮影間隔はこの振動波の 周波数によって規定されることになり，キャビテ イダンパを通過したレーザ光の出力は連続光で

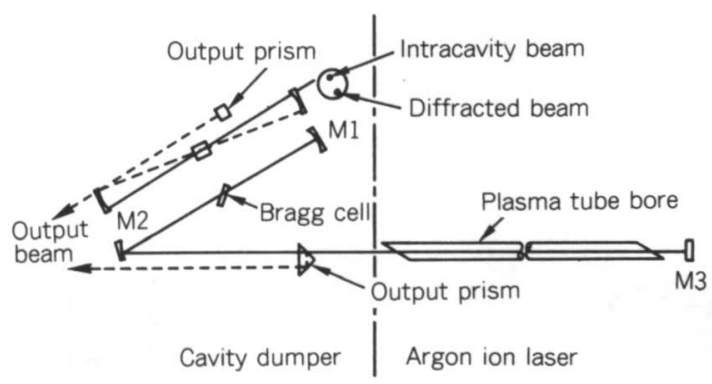

図 6 キャピティダンパの作動原理
5 6W, $400 \mathrm{kHz}$ 発振の状態で平均化した出力は 約 $3 W$ 程度であった。キャビティダンパは, 製品と しては常時発振を継続するので, トリガパルスの パルス幅に対応する時間, 設定した周波数で発光 するように回路の簡単な改造を行った。このキャ ビティダンパ (Spectra Physics製3295) とアルゴ ンイオンレーザ (Spectra Physics製2030出力35 W）を組み合わせることでパルス幅15nsで段階的 に発光周波数 $4 \mathrm{kHz} \sim 4 \mathrm{MHz}$ (パルス間隔 $250 \mathrm{~ns}$ $\sim 2.5 \mathrm{~ms}$ ) の発振が可能となる。発光間隔と回転鏡 の回転数を適切に選べば, 解像度を低下させるこ となく, 最大撮影速度 $4.0 \times 10^{6} \mathrm{fps}$ で, 駒数 80 程度 までの撮影が可能である。さらに，8面の回転鏡 に代えて 4 面鏡を使用し, $\mathrm{L}_{\mathrm{A}}$ のみの 1 チャンネ ル, または $\mathrm{L}_{\mathrm{B}}, \mathrm{L}_{\mathrm{C}}$ の 2 チャンネル記録を行う場 合, 駒数約 160 が可能である。加之て, 回転鏡の回 転速度を適当に選び, 連続光源を用いて現象をス リットを通して観測すれば, 最大掃引速度100ns／ mmでストリーク撮影もできる。さらに記録でき るフィルム上の長さは約 $500 \mathrm{~mm}$ と長く, イメージ コンバータ式カメラの記録長さの 7 倍に達する。 すなわち, この時間精度で $50 \mu \mathrm{sec}$ という長時間の 間記録ができることになる。したがって, 試作し たカメラは, 衝撃波現象を観測するためのストリ 一クカメラとしても十分な特性を持つ。

光源に使用したアルゴンイオンレーザおよびキ ヤビティダンパの駆動パルス入力から発光までの 時間遅れは, 計測の結果 $1 \mu \mathrm{sec}$ 以下であった。現象 とアルゴンイオンレーザ光の同期には遅延回路を 適宜組み込み, 完全な同期撮影が可能である。

\section{2 .2 空間分解能試験}

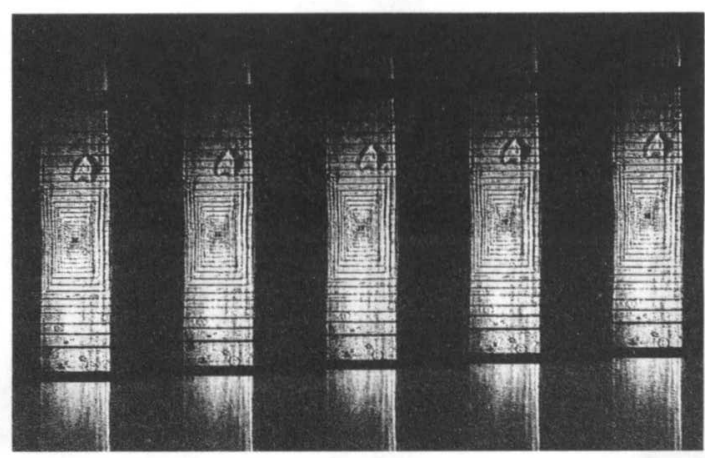

図 7 テストチャートの撮影例 $\left(8.0 \times 10^{5} \mathrm{fps}, \mathrm{Ar}\right.$ レーザ $)$ 


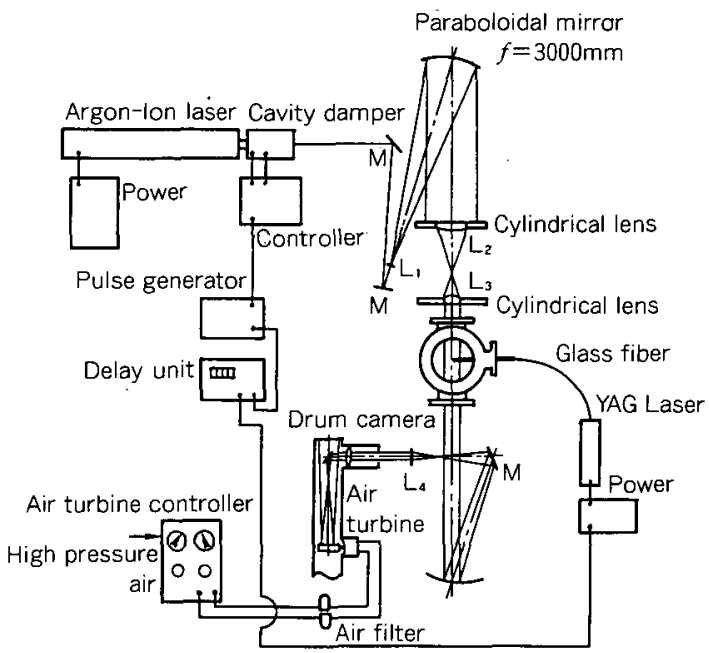

図 8 撮影装㯰の概略

図 7 に毎秒 $8.0 \times 10^{5}$ 駒相当の撮影速度で，テス トチャートの像を記録した結果を示す。光学系は 影写真系で，平行光線光路上に円筒レンズを 2 枚 組み合わせ，光強度の增大を計った。図 8 にこの 撮影装置の概略を示す。撮影には 8 種類のフィル ムと 4 種類の現像液の組み合わせを試行錯䛊した 末，最も增感が可能であるという結果が得られた フジ ネオパン super PRESTO1600 (ASA 1600) を使用し，フジアートドール現像液で, $29^{\circ} \mathrm{C} 25$ 分 間の増感現象を行うという方法をとった。この処 理は，フィルムの技術資料の範囲を大幅に超える ものであり，具体的な数值をあげることはできな いが，実効感度はASA3200をはるかに上回ってい ると考えられる。

さて，イメージコンバータカメラを用いた場合 の撮影では，プレート間で電子ビームを偏向する ので，高速撮影では画像の周囲が多少ゆがむのは 避けられない。一方，試作したカメラの撮影像を 見ると，その歪みは非常に少ない。また，機械的 なシャッターを用いずに，光源の非常に短いパル スを用いているので，回転鏡が高速回転しても像 のぶれはほとんど現れない。さらに，画像の空間 解像度は $4.0 \times 10^{6} \mathrm{fps} て ゙ 25$ lines $/ \mathrm{mm}$ 程度に達し, イメージコンバータカメラの解像度 $\left(1.0 \times 10^{6} \mathrm{fps}\right.$ で10 lines $/ \mathrm{mm}$ ) を大き上回っている。しか も, フィルム上での画像の大きさは 3 大 $5 \mathrm{~mm} \times$ $25 \mathrm{~mm}$ と,イメージコンバータ式カメラで撮影駒
数16の場合の画面サイズにほぼ相当する。この大 きさで後述のように最大 $160 コ マ$ 程度の撮影が可 能なのである。撮影速度では $2.0 \times 10^{7} \mathrm{fps}$ というイ メージコンバータチューブ式カメラも存在するが, 最大コマ数が制限され，解像度についても，その 特性上どうしても少る。したがって，光源を適切 に選択することで，この比較的単純なカメラであ っても十分に極限的状況の観察が可能である。

なお，フィルム面上での空間解像度の計測は JISB7174「写真レンズの解像力測定方法」に準じ, 撮影倍率0.2411, テストチャートはGRATICULES 社製NBS5分解能テストチャートを使用した。

\section{2 .3 適用例}

図 9 (a) (口絵 3 参照)に，大気中で図 5 と同様

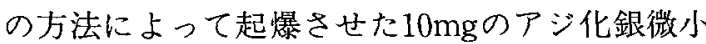
爆発の, 試作ドラムカメラによる撮影結果を示す。 この時のタービン給気圧力は $0.19 \mathrm{MPa}$, 回転鏡の 回転数は約 $130,000 \mathrm{rpm}$, 撮影間隔は $1.25 \mu \mathrm{s}(8 \times$ $10^{5} \mathrm{fps}$ 相当) である。起爆直後，爆発生成気体界面 と，駒動される衝撃波とは密着していてよく分離 されず，双方の区別はできない。7 駒め $(8.75 \mu \mathrm{s}$ 後）から一部衝撃波が分離されはじめ，観察可能 となる。爆発生成気体は爆発の初期では大きな密 度を持ち加速的に膨張する。一方，前方の空気は 低密度なので，この両者の組合せでは高密度気体 層が低密度気体層の方向に加速され RayleighTaylor不安定を生じる。この結果，爆発生成気体 は円凸状となり，初期の段階ではこれにより駆動 される衝撃波も凹凸状を示す。一方，拡大する衝 撃波は安定なので，時間の経過と共に衝撃波は球 状に移行している。

図 9 (b) は同一の現象を試作カメラを用いてス トリーク撮影したものである。この掃引速度は約 $0.5 \mu \mathrm{s} / \mathrm{mm}$, 記録長は約 $500 \mathrm{~mm}$ である。爆発生成 気体と衝撃波の分離過程をはっきりと観察するこ とができる。これらの写真解析から，ある程度以 上の大規模爆発について，成立が確認されてい $た^{55,6)}$ 自己相似解7が，ここで示した薬量わずか 10 $\mathrm{mg}$ の点爆発に对しても, 爆発生成気体と衝撃波が 分離して観測されないような強い衝撃波の領域に ついては十分適用できることが分かっだ”。した がって，適切な光学観測方法を導入すれば，大規 

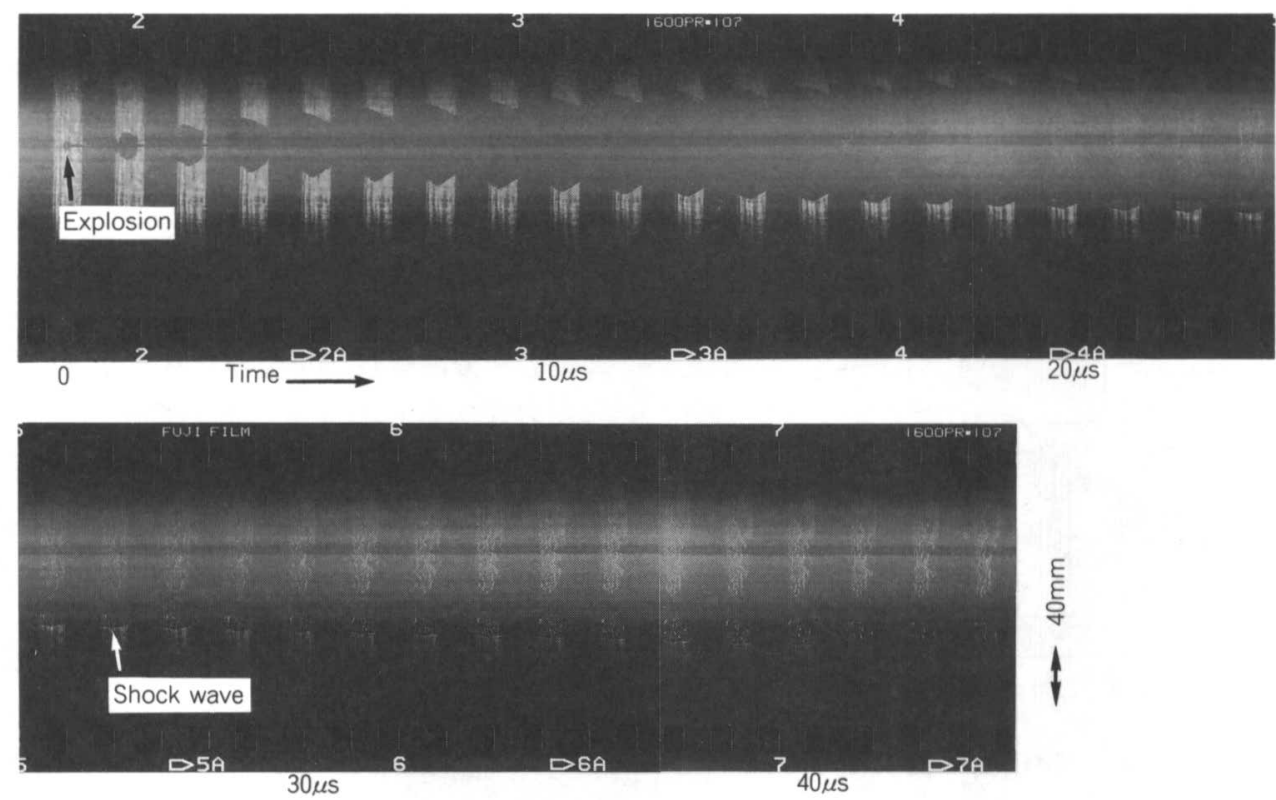

(a) フレーミングモード撮影 $\left(8 \times 10^{5} \mathrm{fps}\right)$
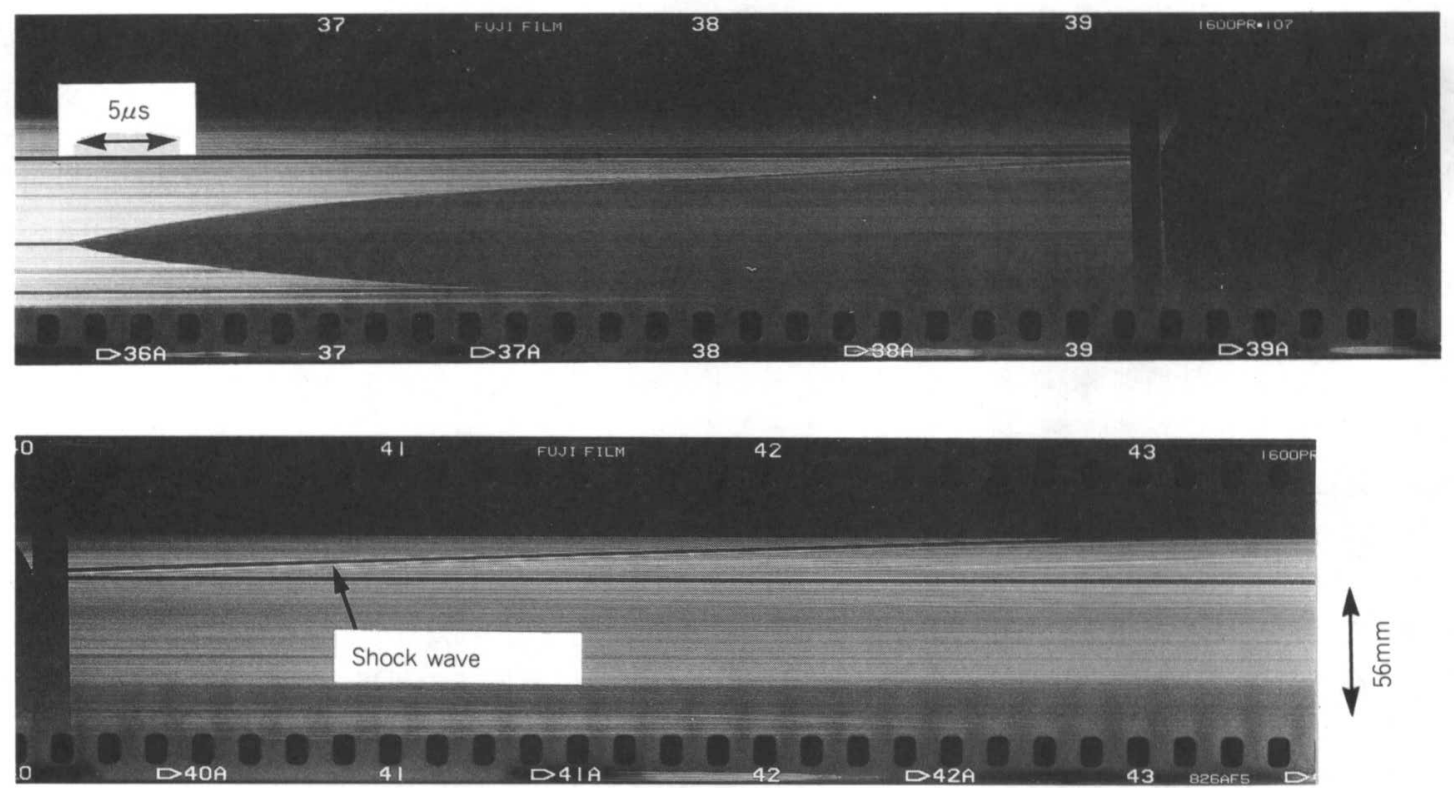

(b) ストリークモード撮影 $(0.5 \mu \mathrm{s} / \mathrm{mm})$

図 9 気中微小爆発の可視化例 $\left(\mathrm{AgN}_{3}-20 \mathrm{mg}, \mathrm{Ar}\right.$ ーザ, シャドウグラフ法

模爆発に伴う衝撃波の挙動を実験室内の微小爆発 で模擬することも十分可能であることになる。な お, 結果の計測には, 写真の画像情報を C C D カ メラ(JVC TK870)で取り込み, 画像処理システム （日本アビオニクス製SPICA II）に入力・処理 し, 中心軸上での画像の濃度分布から衝撃波等の
位置を求めるという方法をとった。また，上記の 画像処理システムでは判別の難しい駒については 副尺付き読み取り顕微鏡により精度確認し処理し た。

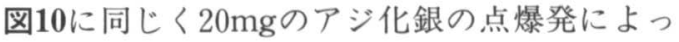
て発生した球状衝撃波が, 剛体壁および軟多孔質 


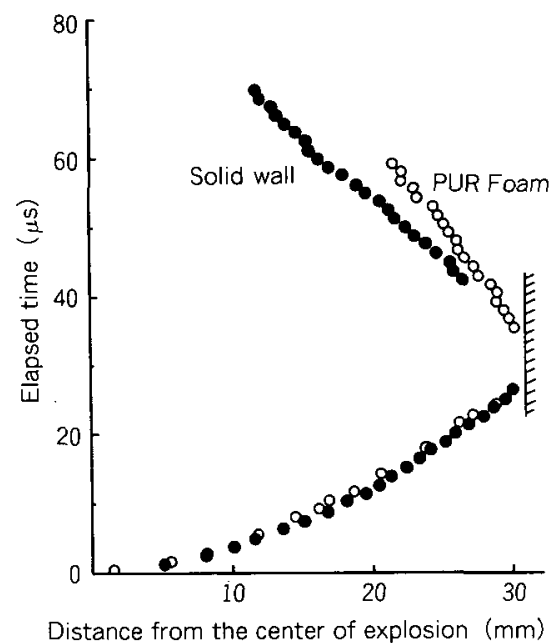

図10 球状衝撃波の壁面での反射解析例 $\left(\mathrm{AgN}_{3}-20 \mathrm{mg}\right)$

壁で反射した場合の波面の軦跡の計測結果を示す。 反射直後は, 波面の干渉もあってはっきりと確認 できない部分もあるものの, 全体としては $1.25 \mu \mathrm{S}$ の時間解像度で56コマ, 総計で70 $\mu$ s撮影を行って いる。これまではストリーク撮影でしか可能でな かった,このような長時間・高解像度の駒どり撮 影も可能となった。

このように試作カメラの記録画像数が多いこと は，ここで試みた点爆発での衝撃波の初生のよう な高速の現象はもちろん, 移動速度は遅くとも高 周波数の変動成分を持つ現象の可視化計測も可能 とする。さらに，現象の開始時間遅れが非常に不
安定で正確にトリガが掛からないような現象の記 録にも対応できる等の利点があげられる。

なお，写真中央部に横に走る明線は，キャビテ イダンパからのもれ光の影響による。本実験では これを防ぐ特別な工夫は施さなかったが，これは 光路上に適当な電磁式のシャッタを用い，キャビ ティダンパ発振時のみ光路を解放することで十分 低減が可能である。

\section{おわりに}

本ドラムカメラの開発により, 平成 3 年度可視 化情報学会技術賞をいただくことができた。足掛 け 3 年にわたる努力が報われた感があり，非常に 感謝なことであった。改めてここにお礼を申しあ げたい。また末筆ながら，開発に当たり熱心なご 指導をいただいた東北大学流体科学研究所高山和 喜教授に心から感謝の意を表する。

\section{参考文 献}

1）例之ば，大川：工業火薬協会誌，13-4,247-258(1952)

2）例之ば, 須藤：工業火薬協会誌，15-4,277-281(1955)

3 ) Onodera, H. et al. : Rep. Inst. Fluid Sci., Tohoku Univ., vol. 2, 49-62(1991).

4）小野寺ほか2 名：日本機械学会諭文集，57-534B，545550 (1991).

5) 例えば,Baker, W.E., Explosions in Air, Univ. Texas Press, Austin, 1973.

6) Saito, T. and Glass, I. I. : Proc. R. Soc. Lond. A384 (1982) 217.

7) Guderley, G. : Luftfahrtforschung 18 (1942) 302-312. 


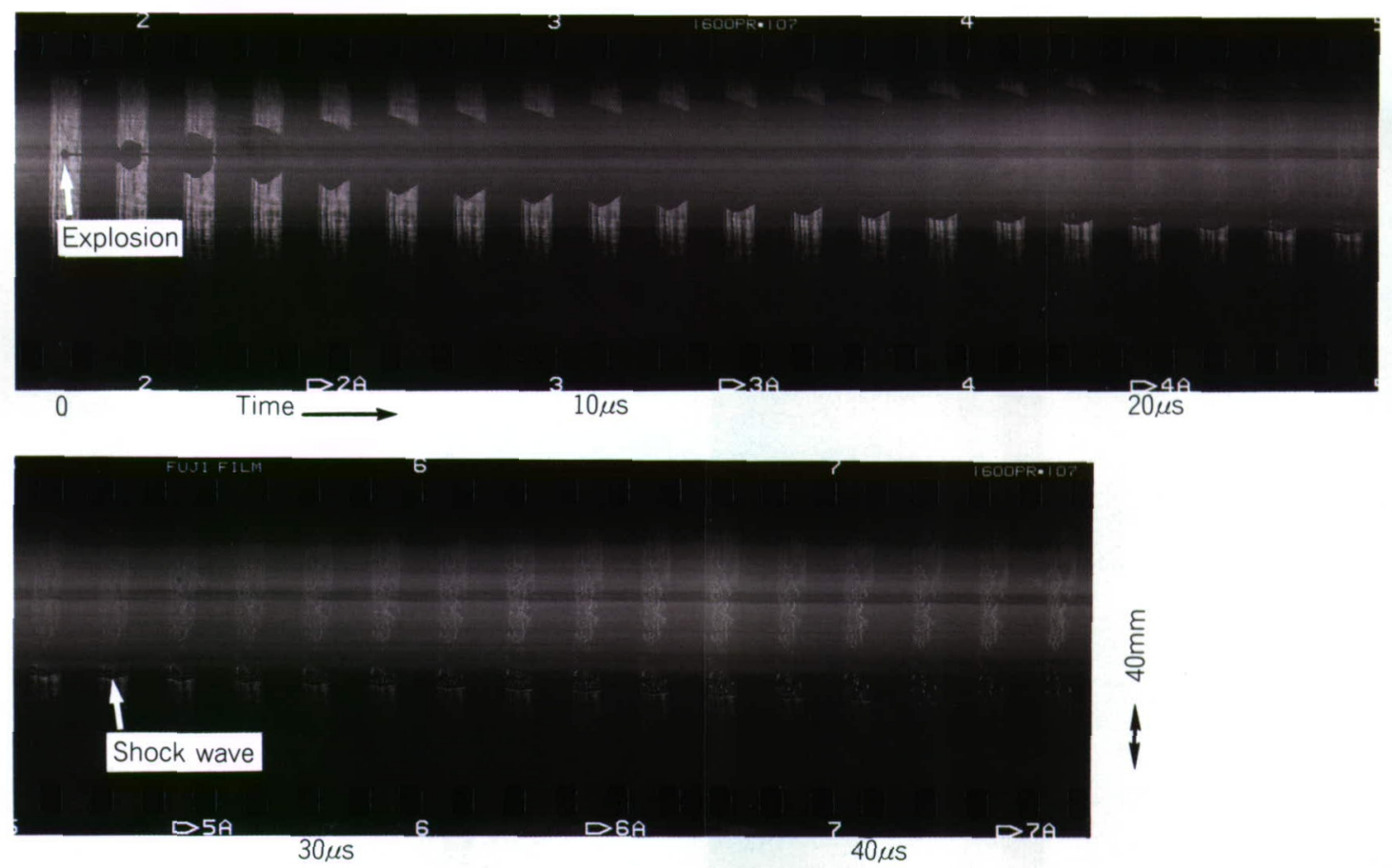

口絵 3 試作回転鏡式高速度カメラを用いて駒撮り撮影されたアジ化銀微小爆発による 爆発生成気体界面と衝撃波(撮影駒間隔は1.25 $\mu \mathrm{s}$ )

(岩手大学 小野寺英輝) (本文93頁参照)

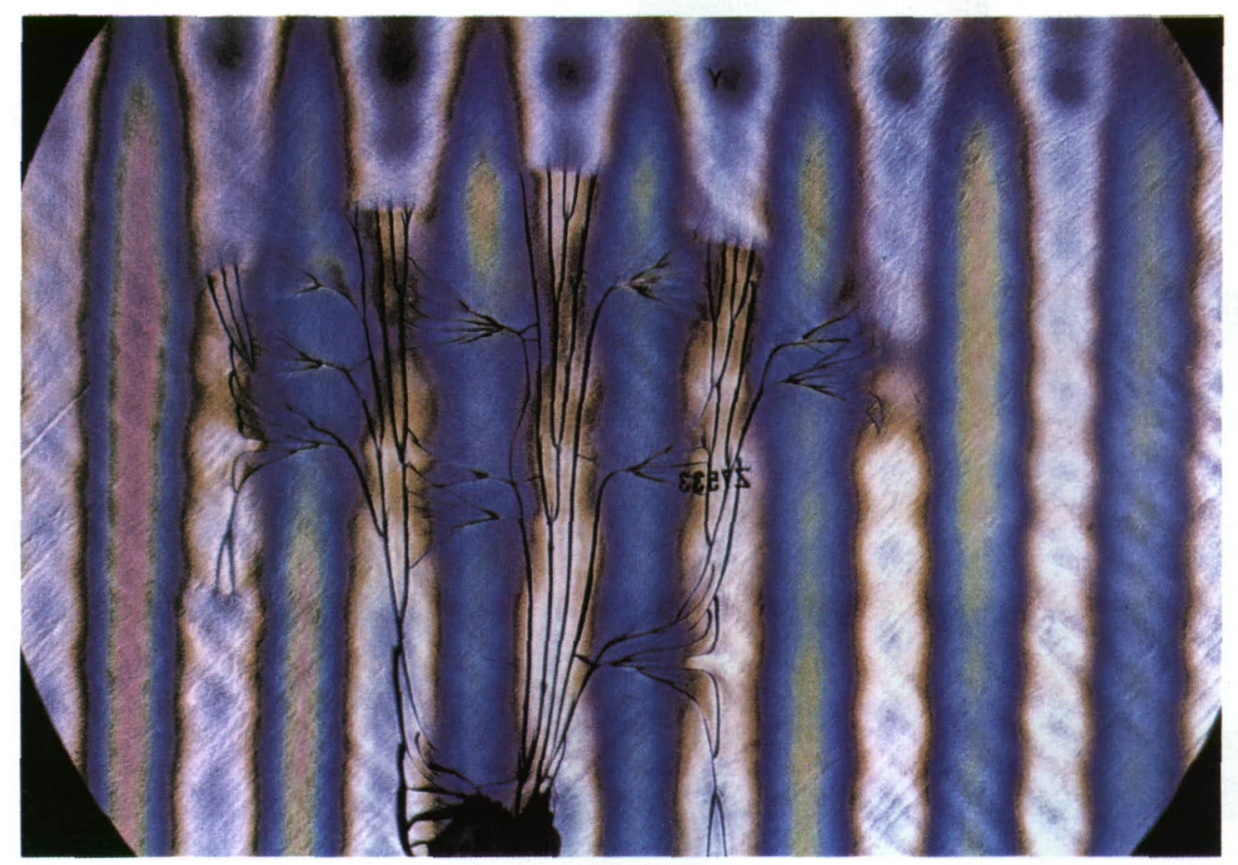

口絵 4 自動車用熱強化ガラス中に生じた衝撃破壊の高速度カラー光弾性写真 (試験片ピント) 